\title{
Multiphasic uptake of D-glucose by an oligotrophic marine bacterium
}

\author{
Hilde Nissen*, Per Nissen* and Farooq Azam
}

Institute of Marine Resources, A-018, Scripps Institution of Oceanography, La Jolla, California 92093, USA

\begin{abstract}
Uptake of D-glucose in the range $2.5 \times 10^{-9} \mathrm{M}$ to $4.0 \times 10^{-3} \mathrm{M}$ by an oligotrophic marine bacterium, LNB-155, could be represented by 4 phases of a single, multiphasic mechanism. Other kinetic models did not give a good fit. Sharp transitions occurred at about $1.6 \times 10^{-6} \mathrm{M}, 10^{-5} \mathrm{M}$ and $2 \times 10^{-4} \mathrm{M}$. Values for $\mathrm{K}_{\mathrm{m}}$ and $\mathrm{V}_{\max }$ increased regularly upon transition to higher phases. Multiphasic uptake mechanisms in LNB-155 indicate adaptation to living in environments with fluctuating levels of D-glucose. These observations are consistent with the hypothesis that pelagic marine bacteria experience considerable fluctuations in nutrient concentration in their microenvironment.
\end{abstract}

\section{INTRODUCTION}

Recent demonstration of the quantitative significance of bacterioplankton as a link in pelagic marine foodweb (Hagström et al., 1979; Fuhrman and Azam 1980, 1982; Williams, 1981; Azam et al., 1982) has generated much interest in the nature of coupling between production of organic matter and its utilization by heterotrophic bacterioplankton. It appears now that this coupling is very tight (Azam and Hodson, 1981; Azam and Ammerman, 1983). The bulk-phase concentrations of bacterial nutrients such as amino acids and saccharides are low and are maintained within narrow limits (Mopper et al., 1980; Burney et al., 1981) apparently due to efficient uptake by marine bacteria. It is of interest therefore to elucidate bacterial uptake mechanisms responsible for this tight coupling.

It had been assumed in the past that pelagic marine bacteria have very low $\mathrm{K}_{\mathrm{m}}$ transport systems compatible with the substrate concentration in seawater (Wright and Burnison, 1979). Recently, it was shown that, in addition to the expected low $\mathrm{K}_{\mathrm{m}}$ (nanomolar) transport systems, assemblages of marine bacteria express progressively higher $\mathrm{K}_{\mathrm{m}}$ transport systems up to $10^{-4} \mathrm{M}$ (Azam and Hodson, 1981). The interpretation of these multiphasic kinetics for species-specific uptake is unclear. There could be 1 uptake system (or mechanism) for each bacterial species or the mul-

- Present address: Department of Microbiology and Plant Physiology, University of Bergen, N-5000 Bergen, Norway

(c) Inter-Research/Printed in F. R. Germany tiphasic kinetics could be due to 2 or more independent mechanisms in the same bacterium. At the species level another possibility is that the uptake might be truly multiphasic, i.e. be mediated by a single membrane structure which changes its characteristics in an all-or-none fashion at certain critical external concentrations of the substrate (Nissen, 1971; Linask and Laties, 1973).

To examine the various mechanistic possibilities it was necessary to use pure culture of a marine isolate. We chose an oligotrophic marine bacterium, LNB-155, which had been isolated on unenriched seawater agar (Carlucci and Shimp, 1974). Hodson et al. (1979) discovered a biphasic kinetic pattern for D-glucose uptake in this isolate. We undertook a study of the uptake of D-glucose by LNB-155 over a wide concentration range. Kinetic analyses and statistical comparisons of various kinetic models suggest that uptake is mediated by a single, multiphasic mechanism. We discuss the results in the context of the adaptation of marine bacteria to nutrient uptake in microenvironments where nutrient concentrations may fluctuate.

\section{MATERLALS AND METHODS}

\section{Culture conditions}

The marine bacterium LNB-155, isolated by Carlucci and Shimp (1974), was kindly provided by Dr. A. F. Carlucci. Cultures were grown in liquid C-P medium 
(Carlucci and Pramer, 1957) at $17^{\circ} \mathrm{C}$ with shaking. Cells in late exponential phase were harvested by centrifugation $(10,000 \mathrm{~g} ; 5 \mathrm{~min})$, washed with sterile artificial seawater and resuspended in artificial seawater to a density of $0.5-6.7 \times 10^{9}$ cells $\mathrm{ml}^{-1}$. The cells were starved by shaking the suspension for 1 to $2.5 \mathrm{~h}$ on a reciprocating shaker at $17^{\circ} \mathrm{C}$.

\section{Uptake measurements}

Uptake of D-glucose was initiated by adding $1.0 \mathrm{ml}$ of cell suspension to various amounts of a mixture of ${ }^{3} \mathrm{H}$-labeled D-glucose and unlabeled D-glucose. Incubation was for 1 or $2 \mathrm{~min}$ at $20^{\circ} \mathrm{C}$ and was terminated by filtration on membrane filters $(0.45 \mu \mathrm{m}$, Millipore), followed immediately by 2 rinses with ice-cold sterile seawater. Formalin-killed controls were prepared for all experimental samples. In time-course experiments, $15 \mathrm{ml}$ cell suspensions were added to the ${ }^{3} \mathrm{H}$-labeled D-glucose at the desired concentration. Samples $(1 \mathrm{ml})$ were withdrawn every $30 \mathrm{~s}$ and filtered as above. The wet filters were radioassayed by liquid scintillation counting after addition of $1 \mathrm{ml}$ ethylacetate (to dissolve the filter) and $10 \mathrm{ml}$ Aquasol (New England Nuclear, Boston, MA).

\section{Analysis of data}

Isotherms for concentration-dependence of D-glucose uptake were resolved into phases as described previously (Nissen, 1977; see also legend to Fig. 3). Kinetic constants (Table 1) were calculated by means of a Fortran program for minimizing deviations in $\log \mathrm{v}$ (Cleland, 1963). Kinetic models (Table 2) were fitted to the data using a computer program for nonlinear least squares (GAUSHAUS). The reciprocals of the rates were used for weighting.

Kinetic analysis of transport processes, including model fitting, tests for goodness of fit and comparisons between models, has recently been reviewed by Gardner and Atkins (1982). A comparison between continuous models and the multiphasic model is given by Nissen and Nissen (1983).

\section{RESULTS}

\section{Time-course}

Uptake of D-glucose by the marine bacterium LNB155 was linear with time, or nearly so, for at least 5 min both at low, intermediate and high concentrations of the sugar (Fig. 1). The short uptake periods, 2 min at

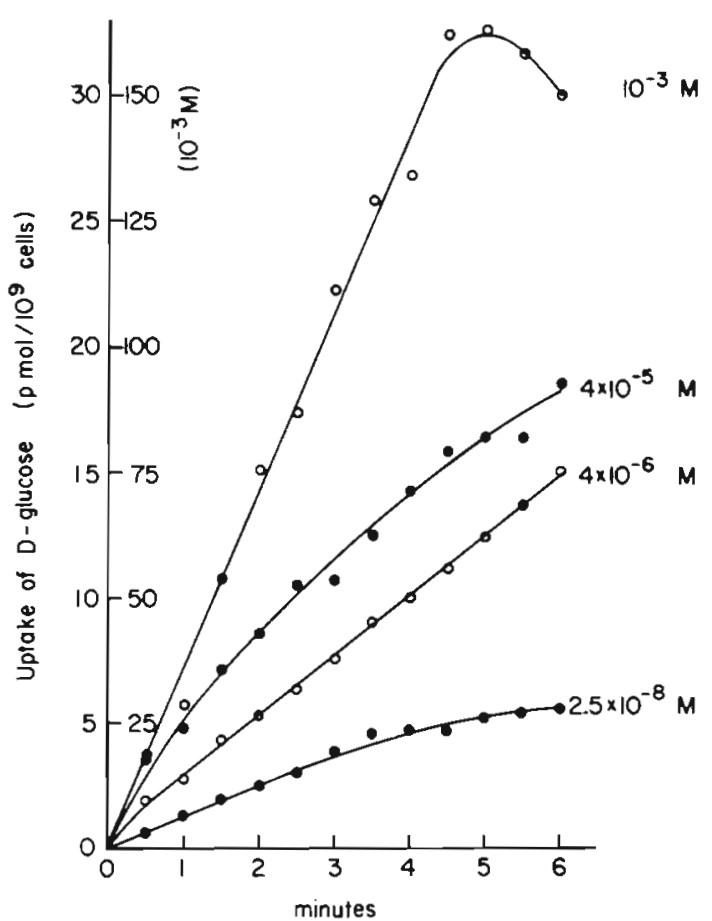

Fig. 1. Time-courses of D-glucose uptake by LNB-155 from 4 different D-glucose concentrations

most, used in the subsequent experiments would therefore tend to preclude complexities due to metabolism of the sugar by the bacteria or to changes in the rate-limiting step.

\section{Concentration-dependence}

The dependence of D-glucose uptake upon external concentration is shown in a series of experiments with overlapping concentration ranges (Fig. 2, 3 and 5). Uptake followed simple Michaelis-Menten kinetics at low concentrations (Fig. 2). At $1.6 \times 10^{-6} \mathrm{M}$ a second phase became apparent while yet another transition occurred at or slightly above $10^{-5} \mathrm{M}$ (Fig. 3). Uptake in the range $2.5 \times 10^{-7} \mathrm{M}$ to $4 \times 10^{-5} \mathrm{M}$ can thus be resolved into 3 phases of a single multiphasic mechanism as exemplified in Fig. 4. At still higher concentrations, a third transition occurred at about $2 \times 10^{-4} \mathrm{M}$ (Fig. 5). The fit to adjacent phases (Nissen, 1977) was in all cases better than the fit to a single phase, often highly significantly so $(\mathrm{P}<0.001)$. It may be noted that the transitions were not due to the use of different stock solutions of unlabeled D-glucose or to other experimental artifacts.

Values for $\mathrm{K}_{\mathrm{m}}$ increased regularly upon transition to higher phases. $K_{m}$ for Phase 1 was about $2 \times 10^{-7} \mathrm{M}$ except for the low (but also uncertain) value for experiment $C$ (Table 1). For Phase $2, \mathrm{~K}_{\mathrm{m}}$ increased by one 


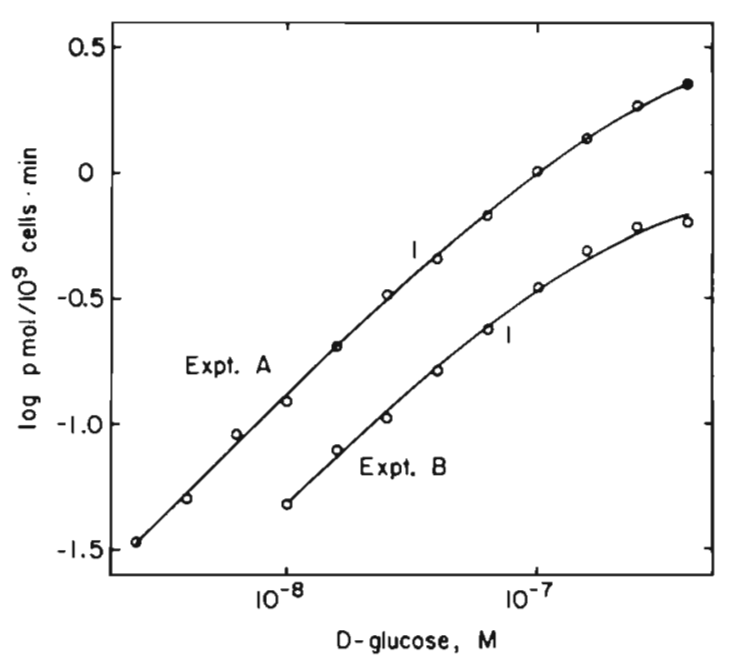

Fig. 2. Uptake of D-glucose by LNB-155. External concentrations: $2.5 \times 10^{-9} \mathrm{M}-4.0 \times 10^{-7} \mathrm{M}$. Expt. A: average $\mathrm{SE}=$ $11.7 \%(n=3)$; Expt. B: average SE $=13.1 \%(n=3)$

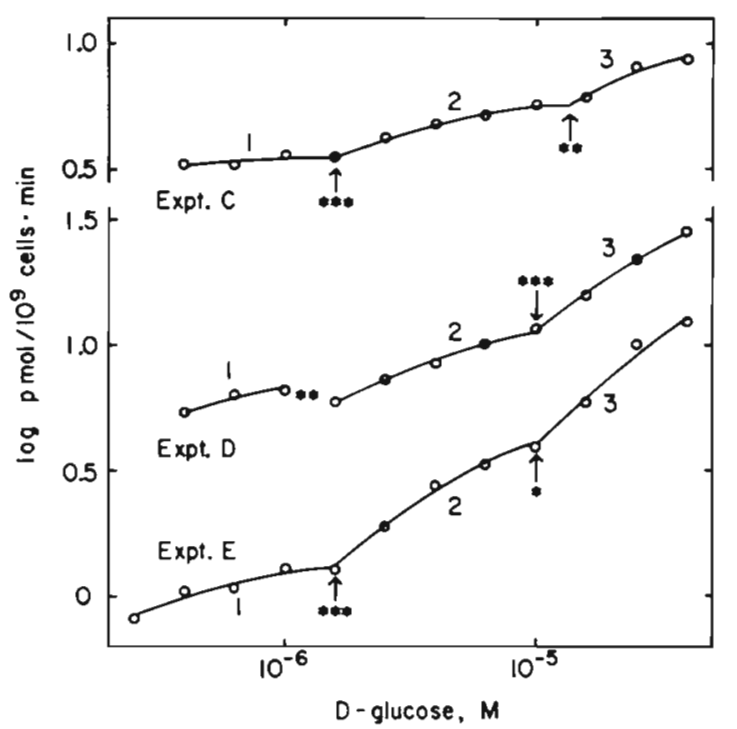

Fig. 3. Uptake of D-glucose by LNB-155. External concentrations: $2.5 \times 10^{-7} \mathrm{M}$ to $4.0 \times 10^{-5} \mathrm{M}$. Arrows: transition points. Significance of fit to adjacent phases (tested against a single phase): $\because 0.01<\mathrm{P} \leq 0.05 ; \cdots: 0.001<\mathrm{P} \leq 0.01$; $\cdots: P \leq 0.001$. See Nissen $(1973,1977)$ for analytical procedure. Expt. C: average $\mathrm{SE}=8.0 \%(\mathrm{n}=3)$; Expt. D: average $\mathrm{SE}=5.7 \%(\mathrm{n}=6) ;$ Expt. E: average $\mathrm{SE}=11.3 \%(\mathrm{n}=4)$

order of magnitude, but there was considerable variation between experiments as apparent from Fig. 3 and shown in Table 1. Similar or even larger increases in $\mathrm{K}_{\mathrm{m}}$ occurred upon transition to Phases 3 and 4 (Table 1). For Phase 4 there was little or no indication of saturation at $4 \times 10^{-3} \mathrm{M}$ (Fig. 5), precluding an accurate determination of $\mathrm{K}_{\mathrm{m}}$ (Table 1 ).

Uptake rates varied considerably between experiments (Fig. 2, 3 and 5), as did values for $V_{\max }$ (not shown). This may be ascribed to differences in the

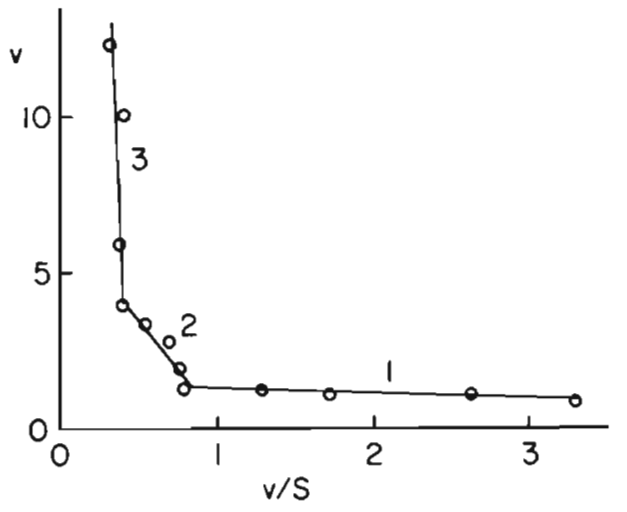

Fig. 4. Eadie-Hofstee plot of the data in Expt. E (Fig. 3)

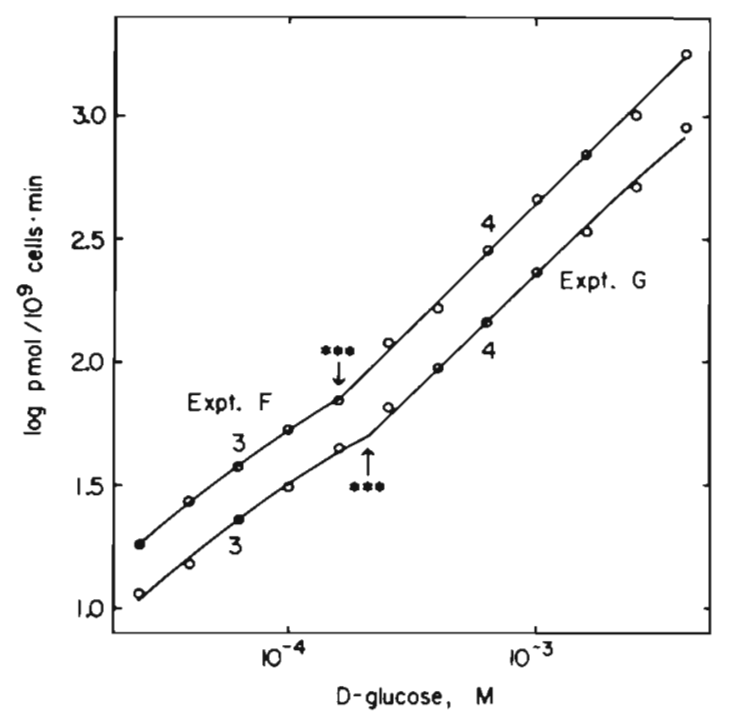

Fig. 5. Uptake of D-glucose by LNB-155. External concentrations: $2.5 \times 10^{-5} \mathrm{M}$ to $4.0 \times 10^{-3} \mathrm{M}$. Arrows: transition points. Significance symbols (asterisks): see legend to Fig. 3. Expt. F: average SE $=5.5 \%(\mathrm{n}=3)$; Expt. G: average $\mathrm{SE}=$ $7.2 \%(n=3)$

starvation of the bacteria prior to uptake (see 'Materials and Methods') and/or to unmonitored differences in the culture conditions. Transition to Phase 2 caused at most a 5 -fold increase in $\mathrm{V}_{\max }$ and transition to Phase 3 at most an 8 -fold increase, i.e. somewhat smaller increases than for $\mathrm{K}_{\mathrm{m}}$. In Experiment $\mathrm{C}, \mathrm{V}_{\max }$ only doubled upon transition to a higher phase (Fig. 3). Transition to Phase 4 increased $V_{\max }$ by 2 orders of magnitude (Fig. 5). It is notable that the phase pattern remained the same despite the variation in uptake rates and $V_{\max }$ (Fig. 3).

\section{Comparison of kinetic models}

Various kinetic models were fitted to the data in Fig. 3 as described in 'Materials and Methods'. The 
Table $1 . K_{m}$-values for the experiments in Fig. 2,3 and 5

\begin{tabular}{|c|c|c|c|c|}
\hline Expt & Phase 1 & Phase 2 & Phase 3 & Phase 4 \\
\hline A & $2.9 \pm 0.2 \times 10^{-7}$ & & & \\
\hline $\mathrm{B}$ & $2.1 \pm 0.2 \times 10^{-7}$ & & & \\
\hline $\mathrm{C}$ & $4.0 \pm 4.9 \times 10^{-8}$ & $1.3 \pm 0.1 \times 10^{-6}$ & $1.5 \pm 3.7 \times 10^{-5}$ & \\
\hline $\mathrm{D}$ & $1.9 \pm 2.7 \times 10^{-7}$ & $2.2 \pm 0.4 \times 10^{-6}$ & $3.7 \pm 0.8 \times 10^{-5}$ & \\
\hline $\mathrm{E}$ & $1.8 \pm 0.5 \times 10^{-7}$ & $6.6 \pm 1.5 \times 10^{-6}$ & $1.8 \pm 1.5 \times 10^{-4}$ & \\
\hline $\bar{F}$ & & & $1.8 \pm 0.1 \times 10^{-4}$ & $1.6 \pm 4.8 \times 10^{-2}$ \\
\hline G & & & $2.0 \pm 0.6 \times 10^{-4}$ & $2.8 \pm 2.0 \times 10^{-3}$ \\
\hline
\end{tabular}

models include the sum of a Michaelis-Menten term and a term which was taken to be directly proportional to the external concentration ('single + diffusion'), the sum of 2 Michaelis-Menten terms ('dual'), the sum of 3 Michaelis-Menten terms ('triple') and the multiphasic model. The multiphasic model consistently gave the best fit (Table 2). The residual mean sum of squares

Table 2. Goodness of fit of various kinetic models to the data in Fig. 3. The weighted mean square of deviates, or residual mean square, $\Sigma v_{\text {obs }}^{-2}\left(v_{\text {obs }}-v_{\text {calc }}\right)^{2} / \mathrm{DF}$ is used as measure of fit. Values in table $\times 10^{-3}$

\begin{tabular}{|c|c|c|c|c|}
\hline \multirow[b]{2}{*}{ Expt } & \multicolumn{4}{|c|}{ Kinetic model ${ }^{*}$} \\
\hline & $\begin{array}{c}\text { Single }+ \\
\text { diffusion }\end{array}$ & Dual & Triple * & $\begin{array}{l}\text { Multi- } \\
\text { phasic }\end{array}$ \\
\hline $\mathrm{C}$ & 8.5 & 5.2 & 4.2 & 1.4 \\
\hline $\mathrm{D}$ & 4.4 & 4.6 & 6.2 & 0.9 \\
\hline E & 13.1 & 12.2 & 17.3 & 3.6 \\
\hline \multicolumn{5}{|c|}{$\begin{array}{l}\text { - See text } \\
\text { Constrained to exclude negative values for kinetic } \\
\text { constants; see text }\end{array}$} \\
\hline
\end{tabular}

was lower for the multiphasic model than for the 3 other models, although only significantly so $(P<0.05)$ in the case of Experiment D. The triple model, the most complex of the continuous models, was furthermore contraindicated by the finding of negative values for one or more of the kinetic constants.

This comparison is biased against the multiphasic model since only a limited concentration range is considered. In a wider range the marked transition between Phases 3 and 4 (Fig. 5) would clearly make the continuous models untenable. A cooperative model based on the interaction of 4 subunits was also found to give a relatively poor fit (data not given). These models can only give gradual transitions and there are good indications that the transitions are indeed discontinuous (Fig. 4) as predicted by the multiphasic model. The all-or-none nature of the kinetics is especially appa- rent when a transition is accompanied by a discontiguity in the isotherm (see transition between Phases 1 and 2 - Experiment D in Fig. 3).

\section{DISCUSSION}

Our results on LNB-155 extend previous observations of multiphasic uptake of glucose by natural bacterial assemblages (Azam and Hodson, 1981). The finding of multiphasic kinetics in LNB-155 in this study raises the question: How general is this type of transport system in marine bacteria? To answer this question adequately would require work with not only a large number of isolates but also a variety of substrates for each isolate studied. The present study can serve only as a model experimental system for investigating the generality of multiphasic transport systems in marine bacteria.

It is interesting that LNB-155 can grow in particlefree unsupplemented seawater, yet its transport system has $\mathrm{K}_{\mathrm{m}}$ values from submicromolar to millimolar. Multiplicity of transport systems is often considered an adaptation to utilizing the nutrient in question in a fluctuating nutrient field. However, the energetic investment in the synthesis and maintenance of multiple transport systems has to be taken into account. Since the average concentration of directly utilizable dissolved organic matter (UDOM) in seawater is quite low, metabolic strategies to forego the need for multiple transport systems, as in the multiphasic transport system here, appear beneficial for the bacterium. The fundamental difference between multiple and multiphasic transport systems should be emphasized in this context. In multiphasic uptake, a single entity (uptake site, carrier, or channel) undergoes abrupt conformational change at certain critical solute concentrations. For ion uptake in higher plants (for which more data are available) it has been demonstrated kinetically that transitions are not caused by interaction of ions with the uptake site but with a separate transition site 
accessible only from outside the plasmalemma (Vange et al., 1974; Nissen, 1980). The molecular basis for discontinuous transitions remains unclear, however.

The finding of multiphasic kinetics for D-glucose uptake in an oligotrophic marine bacterium may help explain previously puzzling results for uptake of sugars and amino acids by natural assemblages of aquatic bacteria. On the basis of a simulation of the kinetics of uptake by heterogeneous populations, Williams (1973) concluded that 'departure from the predictions of the [Michaelis-Menten] equation . . cannot be attributed simply to the fact that the population is heterogeneous'. The departure in question (Vaccaro and Jannasch, 1967; Munroe and Brock, 1968; Hamilton and Preslan, 1970) may, at least in part, have resulted from D-glucose uptake being multiphasic rather than monophasic. Departures from MichaelisMenten kinetics for uptake of amino acids (Crawford et al., 1974; Barvenik and Malloy, 1979; Geesey and Morita, 1979) may possibly also be explained similarly. Amino acid transport in some bacteria is multiphasic (P. Nissen, unpubl.).

What do these results tell us about the nature of coupling between the production of UDOM and its uptake by bacteria in the seawater? It is reasonable to argue that the high $\mathrm{K}_{\mathrm{m}}$, high $\mathrm{V}_{\max }$ components of the LNB-155 multiphasic transport system for D-glucose reflect an adaptation to a nutrient field where a broad range of substrate concentrations is encountered by the bacterium. These results thus suggest the existence of microscale variations in nutrient concentrations in seawater. Intracellular concentrations of sugars and amino acids in algae are on the order of millimolar (Dortch, 1982), and similar high nutrient concentrations might exist in microenvironments around sources of sustained production of UDOM such as algae excreting organic compounds or detrital particles undergoing hydrolysis (Azam and Hodson, 1981; Azam and Ammerman, 1983). Multiphasic uptake systems should allow optimum nutrient uptake in microenvironments where the nutrient concentration may vary both in space and in time.

Acknowledgements. We thank D. Osborn and M. Ogle for help in manuscript preparation. This work was supported by NSF grant OCE 79-26458 and US Department of Energy Contract DE-AM03-76SF00010.

\section{LITERATURE CITED}

Azam, F., Ammerman, J. W. (1983). Cycling of organic matter by bacterioplankton in pelagic marine ecosystems: microenvironmental considerations. In: Fasham, M. J. (ed.) Flows of energy and material in marine ecosystems: theory and practice. NATO-ARI, May 1982. Plenum Press, New York

Azam, F., Fenchel, T., Field, J. G., Gray, J. S., Meyer-Reil,
L. A., Thingstad, F. (1982). The ecological role of watercolumn microbes in the sea. Mar. Ecol. Prog. Ser. 10: $257-263$

Azam, F., Hodson, R. E. (1981). Multiphasic kinetics for Dglucose uptake by assemblages of natural marine bacteria. Mar. Ecol. Prog. Ser. 6: 213-222

Barvenik, F. W., Malloy, S. C. (1979). Kinetic patterns of microbial amino acid uptake and mineralization in marine waters. Estuar. coast. mar. Sci. 8: 241-250

Burney, C. M., Johnson, K. M., Sieburth, J. McN. (1981). Diel flux of dissolved carbohydrate in a salt marsh and a simulated estuarine ecosystem. Mar. Biol. 63: 175-187

Carlucci, A. F., Pramer, D. (1957). Factors influencing the plate method for determining abundance of bacteria in seawater. Proc. Soc. exp. Biol. Med. 86: 392-394

Carlucci, A. F., Shimp, S. L. (1974). Isolation and growth of a marine bacterium in low concentrations of substrate. In Colwell, R. R., Morita, Y. (ed.) Effect of the ocean environment on microbial activities. University Park Press, Baltimore, p. 363-367

Cleland, W. W. (1963). Computer programmes for processing enzyme kinetic data. Nature, Lond. 198: 463-465

Crawford, C. C., Hobbie, J. E., Webb, U. L. (1974). The utilization of dissolved free amino acids by estuarine microorganisms. Ecology 55: 551-563

Dortch, Q. (1982). Effect of growth condition on accumulation of internal nitrate, ammonium amino acids, and protein in three marine diatoms. J. exp. mar. Biol. Ecol. 61: 243-264

Fuhrman, J. A., Azam, F. (1980). Bacterioplankton secondary production estimates for coastal waters of British Columbia, Antarctica, and California. Appl. environ. Microbiol. 39: 1085-1095

Fuhrman, J. A., Azam, F. (1982). Thymidine incorporation as a measure of heterotrophic bacterioplankton production in marine surface waters: evaluation and field results. Mar. Biol. 66: 109-120

Gardner, M. L. G., Atkins, G. L. (1982). Kinetic analysis of transport processes in the intestine and other tissues. Clin. Sci. 63: 405-414

Geesey, G. G., Morita, R. Y. (1979). Capture of arginine at low concentrations by a marine psychrophilic bacterium. Appl. environ. Microbiol. 38: 1092-1097

Hagström, A., Larsson, U., Hörstedt, P., Normark, S. (1979). Frequency of dividing cells, a new approach to the determination of bacterial growth rates in aquatic environments. Appl. environ. Microbiol. 37: 805-812

Hamilton, R. D., Preslan, J. E. (1970). Observations on heterotrophic activity in the eastern tropical Pacific. Limnol. Oceanogr. 15: 395-401

Hodson, R. E., Carlucci, A. F., Azam, F. (1979). Glucose transport in a low nutrient bacterium. Abstract. 79th Annual Meeting Am. Soc. Microbiol., Los Angeles, USA

Linask, J., Laties, G. G. (1973). Multiphasic absorption of glucose and 3-O-methyl glucose by aged potato slices. Pl. Physiol. 51: 289-294

Mopper, K., Dawson, R., Liebezeit, G., Ittekkot, V. (1980). The monosaccharide spectra of waters. Mar. Chem. 10: 55-66

Munro, A. L. S., Brock, T. D. (1968). Distinction between bacterial and algal utilization of soluble substances in the sea. J. gen. Microbiol. 51: 35-42

Nissen, P. (1971). Uptake of sulfate by roots and leaf slices of barley: mediated by single, multiphasic mechanisms. Physiologia pl. 24: 315-324

Nissen, P. (1973). Multiphasic uptake in plants. II. Mineral cations, chloride, and boric acid. Physiologia pl. 29: 298-354

Nissen, P. (1977). Ion uptake in higher plants and $\mathrm{KCl}$ stimu- 
lation of plasmalemma adenosine triphosphatase: comparison of models. Physiologia pl. 40: 205-214

Nissen, P. (1980). Multiphasic uptake of potassium by barley roots of low and high potassium content: separate sites for uptake and transitions. Physiologia pl. 48: 193-200

Nissen, P., Nissen, Ø. (1983). Validity of the multiphasic concept of ion absorption in plants. Physiologia pl. 57 : $47-56$

Vaccaro, R. F., Jannasch, H. W. (1967). Variations in uptake kinetics for glucose by natural populations in seawater. Limnol. Oceanogr. 12: 540-542

Vange, M. S., Holmern, K., Nissen, P. (1974). Multiphasic uptake of sulfate by barley roots. I. Effects of analogues, phosphate, and pH. Physiologia pl. 31: 292-301

Williams, P. J. leB. (1973). The validity of the application of simple kinetic analysis to heterogeneous microbial populations. Limnol. Oceanogr. 18: 159-165

Williams, P. J. leB. (1981). Incorporation of microheterotrophic processes into the classical paradigm of the planktonic food web. Kieler Meeresforschungen, Sonderheft 5: $1-28$

Wright, R. T., Burnison, B. K. (1979). Heterotrophic activity measured with radiolabeled organic substrates. In: Costerton, J. W., Colwell, R. R. (ed.) Native aquatic bacteria: enumeration, activity and ecology, ASTMSTP695, Am. Soc. for Testing Materials, Philadelphia, p. 140-155

This manuscript was presented by Professor J. Gray; it was accepted for printing on November 11, 1983 